\title{
Households Vulnerability and Adaptation to Climate Variability Induced Water Stress on Downstream Kaduna River Basin
}

\author{
Okafor G. Chinwendu ${ }^{1}$, S. O. E. Sadiku ${ }^{2}$, A. O. Okhimamhe1, J. Eichie ${ }^{1}$ \\ ${ }^{1}$ West African Science Service Centre on Climate Change and Adapted Land Use (WASCAL) Coordinating Secretariat, Federal \\ University of Technology, Minna, Niger State, Nigeria \\ ${ }^{2}$ Department of Water Resources, Aquaculture and Fisheries Technology, Federal University of Technology, Minna, Niger State, \\ Nigeria \\ Email: *gloriacokafor@yahoo.com
}

How to cite this paper: Chinwendu, O.G. Sadiku, S.O.E., Okhimamhe, A.O. and Eichie, J. (2017) Households Vulnerability and Adaptation to Climate Variability Induced Water Stress on Downstream Kaduna River Basin. American Journal of Climate Change, 6, 247-267.

https://doi.org/10.4236/ajcc.2017.62013

Received: August 10, 2016

Accepted: May 8, 2017

Published: May 11, 2017

Copyright (c) 2017 by authors and Scientific Research Publishing Inc. This work is licensed under the Creative Commons Attribution International License (CC BY 4.0).

http://creativecommons.org/licenses/by/4.0/

\begin{abstract}
Water stress is one of the risks emanating from worsening climatic variations. It poses serious threats on vulnerable continents, people and livelihoods globally. However, little information is available on how the specific climate threat is impacting people's livelihoods and water resources on different temporal and spatial scales in Nigeria basins. This study aimed at investigating household vulnerability and adaptation to water stress induced by climate variability on a downstream Kaduna River basin with the goal of supporting/facilitating climate change adaptation. The research analyzed hydro-climatic data and employed vulnerability-based framework consistent with stakeholders' participatory approach, within the context of current climate conditions experienced, and/or water stress conditions already affecting household livelihoods in six communities at three study sites; Shiroro, Gbako and Lavun, and adaptive strategies engaged to deal with water stress. Findings revealed that households have been exposed and experienced changes in water availability through variations in rainfall, temperature and runoff. Consequently, these changes have impacted on food production and livelihoods. Households have individually and collectively employed adaptation techniques which are reactive, short-term indigenous coping strategies usually adopted during periods of stress to minimize water-related vulnerabilities. The study demonstrated how an understanding of the local household vulnerabilities will enable the recognition of early indicators of water stress in addition to the occurrence of extreme events. Overall, households' vulnerability decreased from one village to another due to differences in sensitivity to stress, access to resources and local institutional capacity. Resilience of households can be increased through early warning system during flood
\end{abstract}


events, providing access to water from rainwater harvesting techniques, and integration of climate change adaptation into policies regarding development initiatives especially in the area of agriculture.

\section{Keywords}

Climate Variability, Water Stress, Vulnerability, Adaptation, Kaduna River

\section{Introduction}

The availability of water and its demand, especially with the advent of climate change have been of international concern [1]. Globally, studies have demonstrated that people are experiencing water stress, especially in sub-Saharan Africa [2] [3]. The World Bank in 2010 stated that water availability and impacts on society would differ for different areas due to future changes in climate. This correlates with climate change and variability studies on water resources [4] [5] [6] with widespread consequences for human societies and ecosystems [7].

Climate variability manifests itself mostly through droughts from higher rates of evaporation caused by warmer temperature, floods from extreme rainfall amounts, soil erosion due to intense rainfall, and periodic El Niño and La Niña conditions resultant events. Nigeria has experienced climatic variations [8] and is vulnerable to changes in climate. Contributing factors include both total runoff and rainfall decrease, increasing temperature and a reduction in soil moisture storage [9]. Some observed serious climate variability impacts include dry spells, erratic and late onset of rainfall, drought, and increased frequency of floods, water pollution, water scarcity and soil erosion.

Kaduna River in the north-central part of Nigeria, a tributary to Niger River, is subject to climatic variations in form of fluctuations in rainfall pattern and increasing temperature trend. This is likely to affect hydrological processes such as evapo-transpiration, runoff, infiltration, percolation and base flow and in turn affect agriculture, hydropower generation, manufacturing and urban development. Reference [10] has noted the natural rainfall variability and runoff decrease of Niger River due to drought and land degradation which will affect its water availability and its tributaries. The river serves for hydropower supply with thousands of people, in its upstream and downstream reliant on the water availability. Inhabitants in the basin are facing problems such as poverty, limited development, climatic and hydrological extremes, including floods and drought, water borne diseases and reduced hydropower generation potentials [11] [12]. With less than $40 \%$ of Nigeria's population having access to potable water, a substantial percentage is at risk of water stress.

Definition of vulnerability in the climate change context is generally associated as the degree of risk and incapability to resist from climate deviations. The knowledge of conditions by which peoples' lives, properties, livelihoods, and other assets are at risk by a hazardous event, in other words, "human vulnerabil- 
ity in specific situations" is fundamental to understanding the impacts of the changing climate and their management. Vulnerability assessments on changing climate evolved to inform decision making on how communities would respond to changing environmental conditions such as climate variability and water stress. Due to the complexity of vulnerability assessment and the climate system, not many studies on the vulnerability of water resources to climate variability are available to date. To address this, researchers have combined biophysical and socioeconomic science [13] methodologies or rely on the Intergovernmental Panel on Climate Change (IPCC, 2007) definition of vulnerability as a function of exposure (E), sensitivity (S) and adaptive capacity (AC). Assessments either focused on a geographic area and related communities, or a particular natural system and socioeconomic stressors [14]. Studies have also considered multiple stressors in different ways, or ways in which they interact and affect vulnerability [15].

Furthermore, a variety of methods, tools and scenario driven models have been developed and employed to assess impacts and vulnerability in climatesensitive sectors at different scales (global, regional, national and local) to examine the implications of climate change and inform adaptation decisions at specific levels [16] [17] [18] [19]. Among the mentioned scales, at least, spatial and temporal units of analysis need to be in line with the purpose of the assessment. Vulnerability assessments have evolved from risk factors to a multidimensional concept, including physical, socioeconomic, environmental and institutional factors. Specific frameworks have been defined and recommended for more effective vulnerability assessments such as [20] [21] [22]. In conceptualizing vulnerability, specific interest of some of them is on climate change adaptation, disaster risk reduction, global environmental change and sustainability science.

In climate change adaptation, various vulnerability assessments have noted the importance of forward-looking approach and suggested assisting the vulnerable group or resource-dependent rural communities to adapt to stresses [23] [24] [25]. Research has shown that vulnerable communities develop profound knowledge, ways of perceiving and responding to changes and variations in climate [26]. Adaptation can be a reactive, unplanned or strategic action commonly referred in literature as people's ability to cope or adjust to threats in a climate change context and its consequences. Indigenous strategies to cope with climatic variability, which depends on adaptive capacity, vary geographically among communities, between socio-cultural settings and individuals, in addition to temporal scales [27].

However, little information is available on how specific the climate threat is impacting people's livelihoods and water resources on different temporal and spatial scales in Nigeria; owing to inadequacies in observations and models. There is knowledge gap with respect to the rural household experience of varying climate conditions, including livelihood susceptibility to harm, and how they are responding or coping with climatic variations. This requires identifying 
processes that shape vulnerability of the local population and their capacity to deal with or adapt to changing climate conditions. Therefore, this research aimed to explore how rural households are experiencing and responding to climate variability induced water stress, factors creating vulnerability, what is supporting or undermining their capacity to react, in the downstream Kaduna river basin at Shiroro reservoir in the past 40 years (1975-2014). The research attempts to address the following questions: 1) what are the observed climate variability and water stress threats households' downstream Kaduna River basin are exposed to? 2) How does water stress induced by climate variability impacts on household livelihoods? 3) How are households downstream the basin vulnerable to climate change 4) what are the major households' responses to water stress currently adopted or existing on the study site?

\section{Materials and Methods}

\section{Case Study}

The source of River Kaduna is the Jos plateaux (with altitude $1280 \mathrm{~m}$ ) which flows through Kaduna town into Niger state and meets the Niger River at $\mathrm{Nu}$ peko [28]. Downstream catchment of the Kaduna River is found in Niger state, and comprise of Shiroro reservoir watershed and stretches to Lavun (Figure 1). Niger state lies within the Northern Guinea Savannah Zone of Nigeria with sub-basin location of latitudes $09^{\circ} 06^{\prime} 32.64^{\prime \prime} \mathrm{N}$ to $11^{\circ} 30^{\prime} 12.64^{\prime \prime} \mathrm{N}$ and longitudes of $05^{\circ} 30^{\prime} 39.34^{\prime \prime} \mathrm{E}$ to $07^{\circ} 04^{\prime} 44.34^{\prime \prime} \mathrm{E}$. the state is the third most affected in 2012 flood occurrence with 6 LGAs submerged $-1502 \mathrm{~km}^{2}$ [29]. Out of the whole Kaduna basin area of $45,606 \mathrm{~km}^{2}$, the sub-basin makes up $45 \%$ and its annual precipitation ranges between 1100 to $1500 \mathrm{~mm}$ with distinct wet and dry seasons with an annual evaporation loss ranging between $2480 \mathrm{~m}$ and $4350 \mathrm{~m}$. The Shiroro dam reservoir $\left(320 \mathrm{~km}^{2}\right)$, situated on the eastern part of Niger state was built primarily for purpose of supplying needed energy to power the country's growing economy of about $500 \mathrm{MW}$ commissioned in 1990. The study location is characterized by highly variable topographic structure and low relief. Surface Runoff in this location also undergoes large seasonal fluctuations consisting of a peak in August [30] and a trough in March pursuing the seasonality of rainfall in the basin. Dominant soil types are clay mixed with sand or soils are characterized by clay mineralogy. Predominant land use and land cover in the basin are cultivated farmlands mainly rain-fed crops, forest, rocks, bare soil, settlements and water body. The study site known traditionally as rice growing area [31] is among the most populated area in Niger State inhabited mostly by farmers and fishermen. Kaduna River serves as a main source of drinking water supply for underground water in the communities.

\section{Data and Methods}

The historical daily rainfall and temperature data (1975-2014) from two nearby stations provided by NIMET Abuja were used to analyze changes in climate patterns. The available daily runoff (1990-2014) of the Shiroro reservoir was provided 


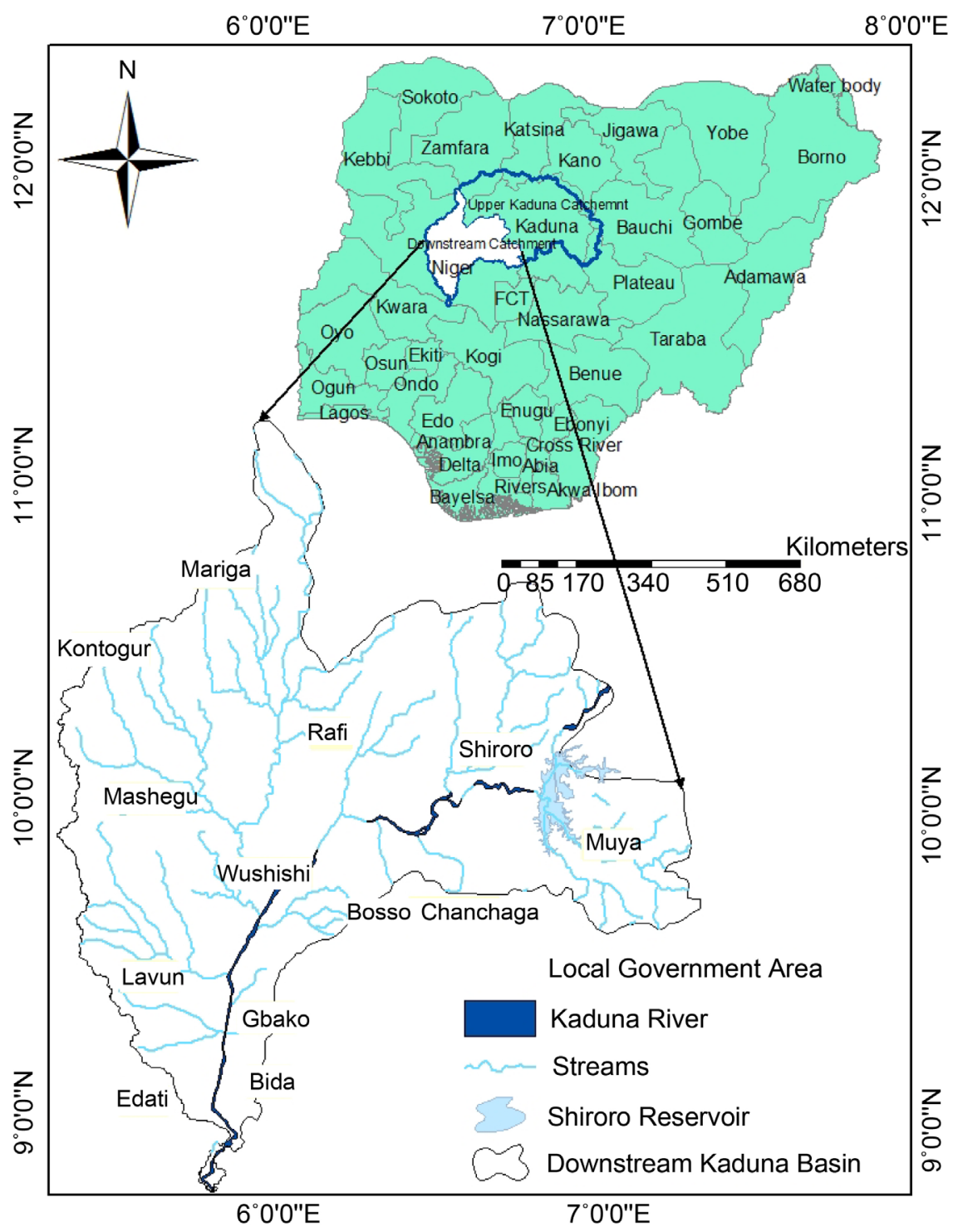

Figure 1. Map of downstream Kaduna river basin location.

by Shiroro hydroelectric power station, Niger State. The mean of the daily data was used to obtain the Monthly and annual values while Monthly values were averaged to obtain seasonal rainfall and temperature for the stations.

The trends of runoff, precipitation and temperature series from 1975 to 2014 in the Kaduna river basin were examined in this study using trend lines with respect to the mean annual and seasonal values for the entire period of study (1975-2014). This gave insights to the temporal variations of rainfall, temperature and runoff, if there exists increasing or decreasing trends in their distribution and variations in dry and wet periods during the forty (40) years.

To examine vulnerability and investigate adaptation to water stress conditions, the study adopted a place specific (sub-basin) and vulnerability-based method involving affected communities. Having defined the system and chosen both spatial and temporal scales, Participatory approach was adopted, to enable better identification of the most vulnerable and threats faced particularly where 
detailed information (such as historical records of river discharges) required for model-based vulnerability analysis are not available. Given the goal of vulnerability assessment in downstream Kaduna basin as climate change adaptation, the vulnerability of households was conceptualized in this study as a function of a systems' (households) exposure to climate conditions (or stressor), their sensitivity, and adaptive capacity to cope or deal with these conditions [27] [32] [33]. The required information on vulnerability revolved around various components summarized as bringing together climate change, water resources aspects and socioeconomic communities; an integrated approach proposed in [34] using combination of both socioeconomic and biophysical indicators.

Indicator or indices approaches that allow involvement of different perspectives in multi-criteria evaluation have been recently recommended and applied by specialists for purpose of reframing public policies as regards vulnerability and risk reduction. Generally, there exist two approaches for indicator selection: 1) the deductive method which is centred on a theoretical understanding of relationships, and 2) the inductive method which is founded on statistical relationships existing among a large number of variables. Reference [25] is suggested for further reading on indicators. The indicator approach here is used to determine vulnerability or risk that is difficult to measure directly. Indicators have been widely used to study phenomena such as environmental degradation, human development, vulnerability and sustainability by using representation data to represent factors such as ecological stress, inequality and well-being status [33]. The use of indicators seeks to capture the physical and/or social determinants or drivers of vulnerability rather than measure vulnerability [35]. Following a deductive approach, the most relevant/prioritized representative indicators (listed in Table 1) used for the analysis were chosen based on knowledge of the

Table 1. Indicators of household vulnerability and water stress as used in the study.

\begin{tabular}{|c|c|c|c|}
\hline $\begin{array}{l}\text { Vulnerability } \\
\text { Components }\end{array}$ & & Elements & Indicators \\
\hline Exposure & $\begin{array}{c}\text { Current water } \\
\text { availability }\end{array}$ & $\begin{array}{l}\text { Rainfall, temperature and } \\
\text { river runoff }\end{array}$ & $\begin{array}{l}\text { Historical patterns, observed trends } \\
\text { and occurrence such as } \\
\text { perceived warming and rainfall }\end{array}$ \\
\hline Sensitivity & & $\begin{array}{c}\text { Degree of climate } \\
\text { variability, water stress, } \\
\text { and extreme events such } \\
\text { as Flood and drought }\end{array}$ & $\begin{array}{l}\text { Awareness, effects of climate } \\
\text { variability, level of water } \\
\text { availability and water shortage }\end{array}$ \\
\hline $\begin{array}{l}\text { Adaptive } \\
\text { capacity }\end{array}$ & Resilience & $\begin{array}{l}\text { Socio-demographic } \\
\text { characteristics, changes in } \\
\text { livelihood activities, } \\
\text { adaptive measures } \\
\text { employed and } \\
\text { institutional capacity } \\
\text { inform of engagement }\end{array}$ & $\begin{array}{l}\text { Level of education, size of household, } \\
\text { occupation(type of activity and } \\
\text { location)/income diversification, } \\
\text { access to resources/basic services } \\
\text { during normal periods (health, } \\
\text { water, land, education, road networks), } \\
\text { available resources during stress } \\
\text { period (climate information, } \\
\text { warnings), coping measures in } \\
\text { agriculture, water supply } \\
\text { and flood control }\end{array}$ \\
\hline
\end{tabular}


investigated phenomena and main steps involved in recognition in literature, consistency and availability with the involvement and discussions with relevant key stakeholders. As earlier mentioned, vulnerability assessment is an integrated assessment which requires social, economic, ecological and physical data.

\section{Sample Selection and Survey}

Purposive sampling was used to choose three local government areas; Shiroro, Gbako and Lavun for study on the basis of location on the course of Kaduna River; the upper and lower slope positions of Shiroro reservoir. The study sites are located at different altitudes; hence vary in terms of environmental conditions, level of rurality as well as access to infrastructure, goods and services. Six different villages, two in each local government area were then selected under the category of water scarcity and stressed communities, villages with high population density, economic and agricultural activities. Effort was made to select communities with at least 30 - 50 households for representative sample size, with the households sample weighted with household number. The selected communities were Isogi, Dadi, Wuya, Gbadafu, Galadima kogo, and Metundaya. They represent typical rural village types in Niger State. 200 households were randomly selected from the villages and represents about $75 \%$ of the households in each of the villages.

Using stakeholders' participation approach, survey was carried out with the aid of; physical site visits interviews through questionnaire administration and focused group meetings during the field work from April to June 2015. Site visit and transect walk were undertaken to assess the available water sources, land use, socio-economic status, access to infrastructure within the area. Personal observations and photographs were taken where necessary, to substantiate the observations made. The semi-structured questionnaire included list of questions on indicators based on the vulnerability framework (Table 1) administered to collect rural household data addressing issues on climate trends and variability, and water stress impacts on livelihoods sources, assets or other aspects of human well-being such as health, and household adaptation strategies; both agricultural practices and non-agricultural responses in periods of water stress induced by changes in climate. Insights gained from questionnaire were further explored in focused group meetings held in the three local government areas. Focused group meetings to identify and analyze community perceptions regarding historical climatic variability in the sub-basin, knowledge about water stress and how they may get disrupted, its personal experienced impacts on everyday livelihoods, and their responses to those impacts and climatic variations. The groups consisted of participants differentiated according to age and gender to ensure triangulation of the key issues emerging from the household questionnaire and validity of the data.

\section{Results and Discussions}

\subsection{Observed Climate Variability and Changing Conditions}

An analysis of rainfall records for the last 40 years showed obvious oscillation 
and instability (Figure 2). For example, yearly rainfall ranges from $853 \mathrm{~mm}$ in 1981 to $1426 \mathrm{~mm}$ in 2007. The trend line indicates variation in rainfall totals showing significant wet and dry years also observed by [36]. The observed variability in yearly rainfall was in line with the study conducted by [37]. The author reported a slight increase in rainfall amount from irregular rainfall pattern over the Kaduna River catchment. The observed significant wet years followed the flood events that occurred in the area which agrees with the work of [38].

Similarly, a variation in runoff patterns over the last 25 years has occurred (Figure 3). Increase in runoff patterns in recent years has been documented by [39] [40]. This leads to flash flood and is observed as a major threat to agriculture and livelihood [41]. The general trend of increasing mean yearly temperature pattern was observed (Figure 4). The observed warmer temperature corroborates the study by [42] using observation and RCM data over the entire country in the period 1976-2065 and is in line with increasing temperature since 1960s over Africa as reported by [17] and evidence of warming observed across the globe.

Relating statistical results with local experience, almost all the households interviewed in the six villages $(98.1 \%)$ observed there is increased temperature and decrease in rainfall amount and therefore could no longer predict the on the timely onset of the rain. Similar observations were made on awareness and

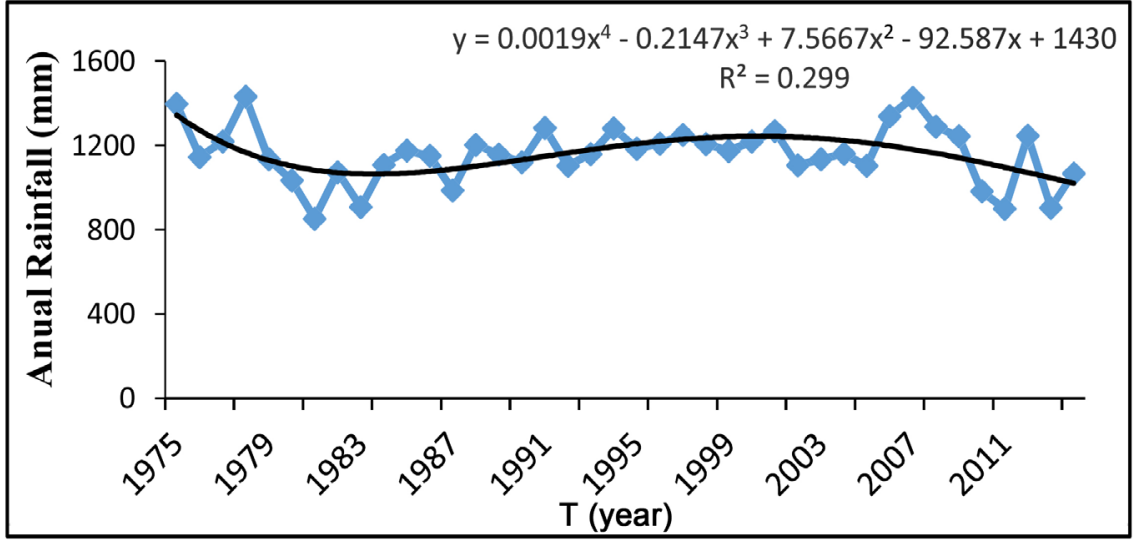

Figure 2. Yearly variations in rainfall patterns (1975-2014).

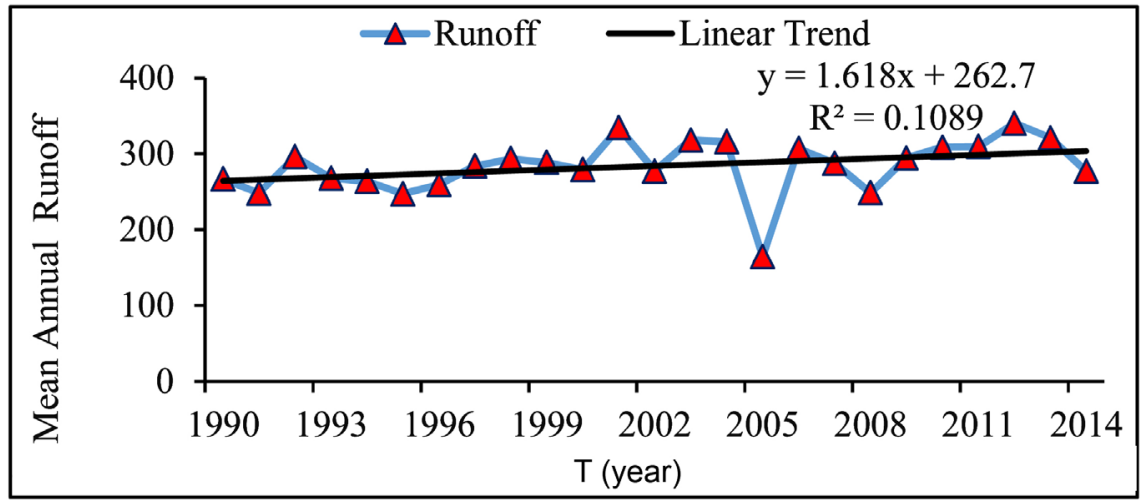

Figure 3. Yearly variations in mean runoff at Shiroro reservoir outlet (1990-2014). 


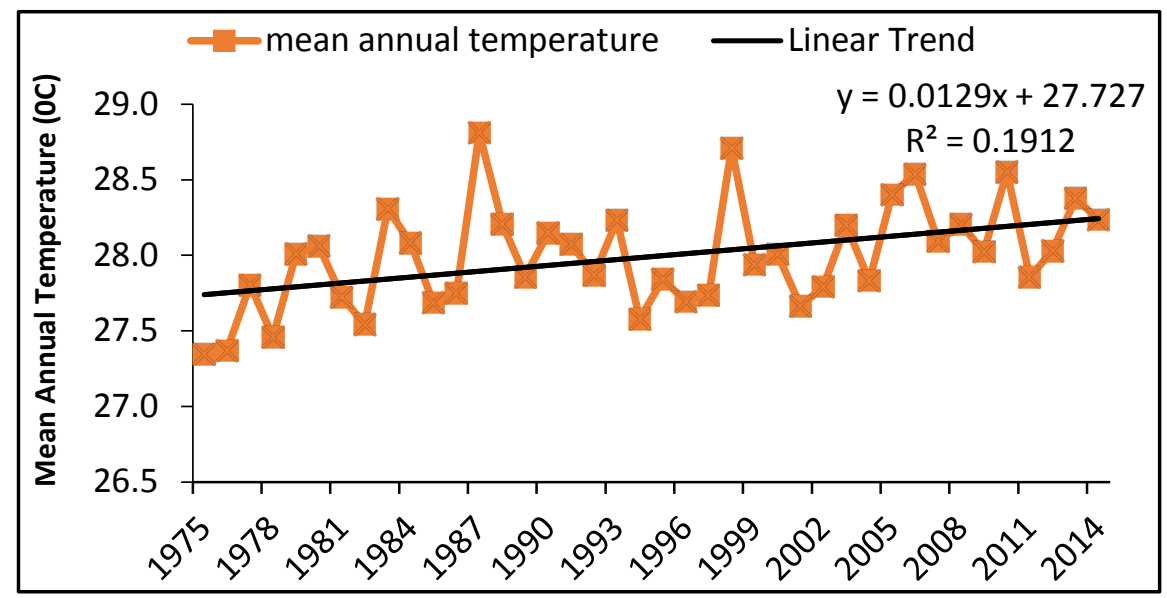

Figure 4. Yearly variations in temperature patterns (1975-2014).

perception of climate changing conditions. The result revealed that most group participants are aware of climate variability and changes from the media (include radio, television, newspaper), village head, personal observations, extension agents and friends but majority became aware via own radio and personal observation. These results support [43] conclusion that vulnerable communities were indicated by integration of local knowledge.

Farming activities has been reported to be affected in Northern Nigeria by low rainfalls and high temperatures [44]. Changes in rainfall amount, intensity and duration contributes to water stress [45]. Group participants noted a decrease in rainfall duration with impact on decrease in water sources, prolonged dry spells, and frequent intense rainfall and flood events which washes of crops. They also observed that heat rashes have become a problem in the recent years because of temperature rise; the sunshine is very scorching and has more heat.

The above results showed that climatic variations are observed at study area and communities have been exposed to water stress. The inter-annual variabilities are related to the upward and downward movement of the inter-tropical convergence zone (ITCZ) as controlled by the monsoon trade winds movement [8] and plays a key role in determining the characteristics of the given climate. An increase in temperature, with increased or decreased rainfall led to water stress in the basin with serious implications for agriculture, domestic water supply and human security. More importantly, this variation in runoff pattern has a direct effect on the very viability of water resource availability in the basin. Without adequate infrastructure in place at the study site to capture and store the excess surface runoff, increased risk of flood and resulting consequences are to be expected especially for the out-of-stream water users.

\subsection{Households Vulnerability and Water Stress}

Consequences of climate variability manifest itself at any time in effects of changes in climatic elements such as temperature, rainfall, all of which have sensitive interactions that ultimately affect the availability of water. This section reports, how these impacts on livelihoods downstream Kaduna River as perceived 
by the locals. Insights were gained through transect walk, focus group meetings, and household interviews through questionnaire administration in the six villages selected from the three study sites-Shiroro, Gbako and Lavun.

\subsubsection{Site Characteristics and Socioeconomic Findings}

The six villages selected; Galadima Kogo, Metundaya, Dadi, Tsoegi Tako Wuya and Gbadafu are rural communities situated within a customary land tenure system, and traditionally have a polygamous patriarchal and nuclear family system. Galadima Kogo and Metundaya are part of a cluster of villages in Shiroro local government with about 100 households of which 75 were interviewed. Galadima Kogo is made up of moderately built up area with large farmlands around homes and settlements located on the floodplain. Dadi and Tsoegi Tako villages in Lavun local government area selected for the study are found very close to Kaduna River. 55 households were interviewed. In Gbako local government, in total of 70 households from two villages of Wuya and Gbadafu were also surveyed. The communities are characterized by poor infrastructure. Households built their houses with mud-blocks or stone, with wood and thatches, as materials for the roofing.

From the survey, the percentage of respondents interviewed is presented in Table 2. The table revealed that majority of respondents were household head. The distribution of respondents' gender showed more of males than female due to cultural structure of the area. Effort was made to get a representative female household head. The dominant age group interviewed was middle aged between

Table 2. Socio-demographic characteristics of respondents in the study sites.

\begin{tabular}{|c|c|c|c|}
\hline Characteristics $(\mathrm{n}=200)$ & Shiroro (\%) & Gbako (\%) & Lavun (\%) \\
\hline Household Head & 70.6 & 59.3 & 70.8 \\
\hline \multicolumn{4}{|l|}{ Gender } \\
\hline Male & 85.3 & 79.6 & 95.8 \\
\hline Female & 14.7 & 20.4 & 4.2 \\
\hline \multicolumn{4}{|l|}{ Age Category } \\
\hline$<20$ & 5.9 & 18.5 & 6.3 \\
\hline $21-40$ & 61.8 & 57.4 & 45.8 \\
\hline $41-60$ & 20.6 & 18.5 & 33.3 \\
\hline $61+$ & 11.8 & 5.6 & 14.6 \\
\hline \multicolumn{4}{|l|}{ Education } \\
\hline No Formal & 39.7 & 22.2 & 22.9 \\
\hline Primary & 17 & 6 & 28 \\
\hline Secondary & 36 & 47 & 30 \\
\hline Years lived in the area & 66.2 & 72.2 & 81.3 \\
\hline \multicolumn{4}{|l|}{ Household Size } \\
\hline $1-5$ & 23 & 52 & 26 \\
\hline $6-10$ & 41 & 34 & 40 \\
\hline $10+$ & 36 & 14 & 34 \\
\hline
\end{tabular}


21 and 40 years showing relatively young head of households. The study reveals that most of the respondents have attained primary and secondary education. This scenario indicated that illiteracy level is minimal. Relatively high education levels and economic status were observed in Gbako communities. Adopting measures to cope with the changing climate are easier and faster among educated people.

The socio-demographic profile in Table 2 showed that the average household size in the study site was found to be between 6 - 10 members. This implies that family dependency is higher especially in Shiroro and Lavun probably due to larger family size and lower education status. The Table also revealed that respondents have lived more than 15 years in the area which indicates better knowledge of the subject matter and livelihood in their communities.

\subsubsection{Sensitivity to Water Stress and Its Contribution to People's Livelihood}

Water is an essential instrument of livelihood support. The available water sources at the study sites include rainwater, River Kaduna (flows all-year round with high quantities of particles in suspension) with very few streams and boreholes that dry up during the dry season which last for five to seven months. Apart from rainwater, the distance of the river sources are a bit far from their houses in the study location. It takes them about 20 minutes on the minimum to get to these sources.

According to the respondents, households consume on average, 150 litres of water per day. Various uses of water by households in the study area include crop farming, livestock farming, irrigation, fishing and domestic uses such as drinking, cooking, and bathing. Water collection is done mainly women and the girl child in these communities. Water availability at most of these earlier mentioned sources are seasonal. The increasingly irregular availability of water threatens the livelihoods of households and smallholder farmers. The analysis indicates that households in Shiroro, are most sensitive to water scarcity. Gbako observed decrease in available water level (58.3\%). This is owing to population pressure, failure and drying up of boreholes resulting from increased hotness, they noted. Maximum impacts of water shortage are likely felt on agricultural growth, economy and wellbeing [46]. Water scarcity is a problem especially in the dry season; people and agriculture suffer more due to increasing dry spells. Meeting rural water supply needs is a major challenge in Nigeria [47]. Households are increasing in size, thus the pressure on the availability and access to safe water, particularly during the dry period, and the increasing dependence on groundwater, are an additional threat. Households in Lavun are the most exposed to water stress and experiences incidents of flood events (87\%). This is because the Kaduna River is the only source of water for the community and houses are built mainly on flood plains.

Review study by [48] showed that about $70 \%$ of Nigerian rural households still lack improved water supply and rely mostly on self-supply. Respondents observed decrease in water supply due to drying up of rivers, streams and ponds. 
This reduces water available for domestic activities such as cooking, bathing and drinking water for both human and livestock. Similar situation have been observed in Niger Delta by [41]. More insect plagues (example mosquitoes) and increasing trend of water and vector-borne diseases such as cholera, malaria, and diarrhoea were reported by participants. They also pointed that erratic rainfall and decreased soil moisture has contributed to reduced soil fertility, poor crop yield and productivity of non-timber forest products (NTFPs). Other studies have also reported crop failure from poor rainfall [24]. Reference [49] has reiterated water stress impact on crop production (e.g. rice) in terms of growth and yield. In the local people's experiences, cases of small droughts are in increasing trend as crops like millet, yam, maize and guinea corn have all been damaged and dried up in the last 5 years because of poor rain. Most of the drought cases were found when there is a need of rainwater such as irrigating rice and millet, have affected forests and pastures with impact on livestock as also reported by researchers [24]. Equally, there were concerns that increasing flood events leads to soil erosion and wash away their farmlands especially those that planted around the river banks.

The indicators of vulnerability is demonstrated in repeated problems of water scarcity and food security in the study area which can be explained by environmental factors such as decreased soil moisture and fertility, soil erosion and flood events. Scientific literatures suggests that water scarcity, dependence on agriculture, income levels, access to land, labour supply, access to credit and information, and gender are some of the factors that create vulnerability [33]. These factors characterize the situation of most people in downstream area of Shiroro reservoir and demonstrates their vulnerability to current climate variability and to future climatic changes.

\subsection{Household Adaptation Responses to Climate Variability and Water Stress}

Water-related impacts of the changing climate demands the highest attention for adaptation owing to severity of such impacts and their socioeconomic implications. Adaptation strategies is essential to reduce households' vulnerability with various existing approaches ranging from modifying threats to preventing effects and to accepting the loss. Reference [50] suggests that prospects to ease some of the increases in water stress, could rely on adaptation measures being taken to utilize increased runoff via increasing storage of seasonal flows. Households in the research area have employed several strategies and practices in response to water scarcity and flood events summarized in Table 3 . To improve their access to available water, they largely store water in drums, pots or basins, conserve water used for different activities and buy ground water. In the group, participants recounted that community meetings and discussions among households from Metundaya is done to solve water issues and provide water by going to the nearest villages to buy water.

Water quality is also essential in determining water security, health and agricultural productivity of households. According to the respondents in Shiroro 
Table 3. Types of adaptive responses.

\begin{tabular}{|c|c|c|}
\hline Water Supply Measures & Agricultural Measures & Flood Control Measures \\
\hline water conservation & Change cropping pattern & Building barriers \\
\hline Storage & Less water intensive crops & $\begin{array}{l}\text { Avoid building on } \\
\text { flood plains }\end{array}$ \\
\hline Seeking alternative source & Short duration crops & $\begin{array}{l}\text { Change of location } \\
\text { (short-term) }\end{array}$ \\
\hline Buying water & $\begin{array}{l}\text { Altering dates for } \\
\text { agricultural operations }\end{array}$ & Migration \\
\hline \multirow[t]{4}{*}{ Water treatment } & Reduce no of livestock's & $\begin{array}{c}\text { Livelihood } \\
\text { diversification }\end{array}$ \\
\hline & Use of chemical fertilizer & \\
\hline & Organic manure & \\
\hline & Mulching & \\
\hline
\end{tabular}

and Lavun, outbreaks of cholera, diarrhoea and other waterborne diseases have been reported. Household water treatment is one of the means of preventing diarrheal diseases and other water related diseases. This is likely because water often becomes contaminated before it is consumed even if it was collected from a protected source. Seven households in Lavun reported treating their water by boiling and adding Alum.

Households at the study site are largely dependent on rain-fed agriculture. In recent years, floods and droughts result in crop damage worth billions of dollars and loss of livestock and human lives [51]. In the group discussions, there were concerns about poor rainfall which lead them to reducing their demand for water by changing cropping patterns and switching to less water intensive crops (for example pepper, vegetables), short duration crops such as maize and cash crops like sugar cane and groundnut, that are less susceptible to water stress, adopting more efficient irrigation practices like planting near the streams, and altering dates for agricultural operations were adopted based on their experiences. Agricultural measures presented in Table 3 have also been reported by researchers [44]. Due to low rainfall all farming activities in Tsoegi Tako and Galadima Kogo are a little distant away from their houses but near the rivers known as Fadama. Households in Shiroro and Lavun reported rainfall loss to surface runoff contributing to high levels of soil erosion. To cope with effect of increase in temperature and water scarcity in agriculture, households in Gbako reduced the number of livestock they keep.

\section{Adaptive Capacity Determinants}

Adaptations are signs of a system's adaptive capacity. Previous studies have emphasized the role of livelihood diversification as a means of adaptation for rural households [52] and proved to be less vulnerable. Households in the study diversified to survive in the event of crop damages by flood. Shiroro is most the populated area with more diversified livelihood activities to reduce their vulnerability to water stress. As a source of income, large proportion (90\%) of all 
households reported engaging in rain-fed agriculture with $31 \%$ of the households practicing irrigation farming.

In addition, most of the households interviewed in Gbako had members working outside the community and urban areas (Table 4). This indicates their contribution to support household livelihood, although no quantitative assessment of how much they contribute was done. As some migrate towards menial jobs in the city, they appear to be adapting well to climatic stresses, but are becoming more vulnerable due to dislocation and disruption of their familiar way of life.

Regarding land ownership system, Table 4 revealed that majority of households interviewed own a farmland with an average size of 1 - 3 hectares per household acquired through inheritance. Social network allows people to act collectively and facilitates adaptation when faced with stress [53]. Respondents belong to cooperative societies in the villages that support them financially and socially, which helps to reduce vulnerability. This shows that these households were interdependent and seek co-operations among themselves, as observed during survey. The social network status was similar in the area, probably due to the downstream and rural specificities.

In general, reports emerging from interviews in the study site revealed that households in the six villages were exposed to climate variability induced water stress in terms of small drought and flood. The decreasing trend of water availability from limited sources for farming and domestic purposes especially during crop production time has increased their vulnerability. The survey revealed that present coping capacity of households in Lavun villages to climate variability and water stress is relatively low than in Shiroro and Gbako villages. They have individually and collectively employed coping strategies such as water storage and conservation practices to improve water availability, water treatment, fertilizer application and short duration crops in order to increase food production, livelihood diversification and migration in the case of flood events.

Table 4. Adaptive capacities of households.

\begin{tabular}{|c|c|c|c|}
\hline Determinants & Lavun (\%) & Gbako (\%) & Shiroro (\%) \\
\hline Awareness of Climate change & 62.5 & 75.93 & 85.29 \\
\hline $\begin{array}{l}\mathrm{HH} \text { member working outside } \\
\text { the community }\end{array}$ & 22 & 40 & 15 \\
\hline Access to land & 87.50 & 96.30 & 92.65 \\
\hline Relatives & 5 & 8 & 14 \\
\hline Assistance & 0 & 5 & 4 \\
\hline Government & 22 & 11 & 12 \\
\hline Irrigation & 6 & 30 & 26 \\
\hline Plant twice per year & 25 & 39 & 40 \\
\hline \multicolumn{4}{|l|}{ Social Group Membership } \\
\hline Farmers' Cooperative Society & 47.4 & 70.2 & 67.1 \\
\hline No Membership & 52.6 & 29.8 & 32.9 \\
\hline
\end{tabular}




\subsection{Constraints and Implications Associated with Adaptation to Climate Variability and Water Stress}

Given the situational analysis of exposure and sensitivity, response to climate variability and water stress was determined by household adaptive capacity which includes site characteristics, socioeconomic profile, livelihood strategies, social network, house types and access to information, provision of infrastructural services and support from external sources, therefore, inadequate provisions of all these limits households adaptive capacity.

Strategies to adjust to the constantly changing environmental conditions necessitate one to be well-informed and knowledgeable [54]. Households in the study location have limited human resources in terms of; being well informed, technology which limits their options in pursuing off-farm employment prospects particularly in Lavun, labour and adequate resources that will enable them to tap available groundwater. Households in the study site rely largely on agriculture. Agricultural land is left barren due to shortage of manpower as younger ones migrate to cities in aspirations for city living standards. Also inadequate funding contributes to water resources management problem for agriculture [55]. Limited job opportunities lead to negative diversification and further depletion of capital assets increasing household vulnerability [18].

Socioeconomic factors constraint is a high indicator essential to accessing factors necessary to adopt appropriate adaptation practices [31]. Access to critical infrastructure and services, such as roads, electricity and telecommunication, plays a role in people's adaptive capacity [56]. The remote and often scattered nature of rural communities presents challenges in accessing markets, information and many services. With bad road connectivity and frequent floods occurrence during the rainy seasons, lack of transportation and marketing facilities in the study area is obviously a prohibitive barrier. Services such as health, education, financial services, and agricultural extension were lacking in some of the villages surveyed and no programme to support adaptation to climate change is in place. Few number of households reported receiving external assistance either from government, NGO or relatives/friends in the form of money, food items, mosquito nets, cement and roofing materials. In the light of changing climate conditions, the local institutional capacity to support people in meeting their basic needs is inadequate, and limits the use of their knowledge and skills in agricultural more effectively. Reference [57] demonstrated the effective support of extension agents in precision agriculture for adaption to climate change.

\subsection{Women's Role in Adaptation}

Clear gender roles were observed within households in the six villages surveyed. Women and girl child have the dominant role of performing most farming tasks and attending to household needs such as fetching water, gathering fodder and firewood, and preparing manure [58]. While men engage in labour demands or intensive activities including felling of trees for firewood and land preparation for farming. Women and girl child in the six villages are the leading collectors 
and providers of water for all domestic purposes. Even at times when the water is very scarce due to drought, they are obliged to walk long distances to fetch water. However, the present study points no significant difference in the use and consumption of water resources between different head of household genders.

In addition, their responsibilities in households and communities (concerning production, collection and storage of food) have equipped them for livelihood strategies adapted to changing environmental realities [59]. Women at the villages are usually prepare, process and store grains, vegetables and fruits using silos during the growing season in order to use them in the dry season when food is scarce. In Metundaya and Wuya village, women sold firewood, sugarcane to earn income, whereas in Dadi village, women farmers come under a group known as "AIEDABA Women Society" to enable them access agricultural credit. This helps to reduce their vulnerability such as providing income for buying water in the stress periods and bouncing back after their properties are damaged by floods.

\section{Conclusions}

The key concern of this study was to investigate household vulnerability living downstream Kaduna River to water stress induced by climate variability and identify existing coping and adaption options with the aim of supporting climate change adaptation. Households in six communities at the three study sites; Shiroro, Gbako and Lavun have experienced a variety of climatic changes, including rising temperatures and changes in precipitation (including increasingly unpredictable and intense rain), extreme climatic events and change in availability of water. Meteorological data shows that varying trends of rainfall and runoff with increasing temperature; major indicators of water stress and flooding in the study area which justifies the local expressed perceived effects of climate variability. Water stress contributed to low crop yields and many people linked these climatic changes to non-climatic stressors e.g. low soil fertility.

The study indicated livelihood strategies, inadequate education, access to resources (land, labour supply and traditional knowledge/information), poor local institutional capacity and services, and gender were the key factors that shape vulnerability and add to increase their vulnerability. To reduce vulnerability, the types of responses reported by households include both short-term coping measures and adaptation strategies such as soil and water conservation practices, diversification and migration, usually adopted, individually or collectively during periods of stress. By management of limited available water and improving existing water sources and development of new strategies, households downstream Kaduna basin have proven to be resilient climatic stressors including water stress, but this is not sufficient in the current ecological changes.

Moreover, changes in climate are intensifying the problems and inequities that women are already facing. It is shown that women in most households in the study area are at the frontline of adaptation to water stress induced by climatic variations, having the major task of collecting and storing food, fuel for 
cooking, and water for all domestic uses. With the erratic weather patterns, they will spend more time on each of these tasks, with less on activities that will reduce their vulnerability such as education, development work and health. Therefore, action is needed to strengthen women's ability to contribute and exercise their unique and valuable perspectives and skills on adaptation to the changing climate.

Overtime, (determining how vulnerability conditions have been created) household vulnerability might increase since important components of present livelihood activities to survive such as deforestation are still sensitive to conditions of the biophysical environment and will adversely increase impacts of climate change on water security, and thus undermine sustainable adaptation. Finding ways to equip communities to better manage extreme variability, while also taking advantage of it, could help increase agricultural productivity. Resilience of households can be increased through early warning system during flood events, providing access to water from rainwater harvesting techniques, and integration of climate change adaptation into policies regarding development initiatives especially in the area of agriculture. Moreover, more contextspecific studies on vulnerability, such as that of the present paper, should be conducted across various basins in Nigeria to understand how climate and hydrological events impacts livelihoods for providing appropriate solutions.

\section{Acknowledgements}

This article is extracted from the research conducted on Kaduna River Basin in April 2010. The study was supported by West African Science Service Centre on Climate Change and Adapted Land Use, a Masters Research Programme fully funded by the German Ministry of Education and Research (BMBF). The authors would like to thank NIMET Abuja and Shiroro HEP Station for providing valuable climatic and hydrological data. We are grateful to people in the study site for their responses and support during the fieldwork.

\section{References}

[1] IPCC (2001) Climate Change 2001: The Scientific Basis. Houghton, J.T., Ding, Y., Nogua, M., Griggs, D., Vander Linden, P. and Maskell, K., Eds., Cambridge University, Press, Cambridge.

[2] Vörösmarty, C.J., Green, P.A., Douglas, E.M. and Revenga, C. (2005) Geospatial Indicators of Emerging Water Stress: An Application to Africa. Ambio, 34, 230-236. https://doi.org/10.1579/0044-7447-34.3.230

[3] Praskievicz, S. and Chang, H. (2009) A Review of Hydrological Modelling of BasinScale Climate Change and Urban Development Impacts. Progress in Physical Geography, 33, 650-671. https://doi.org/10.1177/0309133309348098

[4] Allexandrov, V. and Genev, M. (2003) Climate Variability and Change Impact on Water Resources in Bulgaria. European Water, 25-30, 2003.

[5] Oki, T., Agata, Y., Kanae, S., Saruhashi, T., Yang, D. and Musiake, K. (2001) Global Assessment of Current Water Resources Using Total Runoff Integrating Pathways. Hydrology Science Journal, 46, 983-996. https://doi.org/10.1080/02626660109492890 
[6] Arnell, N.W., Livermore, M.J.L., Kovats, S., Levy, P.E., Nicholls, R., Parry, M.L. and Gaffin, S.R. (2004) Climate and Socio-Economic Scenarios for Global-Scale Climate Change Impacts Assessments: Characterizing the SRES Storylines. Global Environmental Change, 14, 3-20. https://doi.org/10.1016/j.gloenvcha.2003.10.004

[7] Bates, B.C., Kundzewicz, Z.W., Wu, S. and Palutikof, J.P., Eds. (2008) Climate Change and Water. Technical Paper of the Intergovernmental Panel on Climate Change, IPCC Secretariat, Geneva, $210 \mathrm{p}$.

[8] Ekpoh, I.J. and Nsa, E. (2011) Extreme Climatic Variability in North-Western Nigeria: An Analysis of Rainfall Trends and Patterns. Journal of Geography and Geolo$g y, 3,51-62$.

[9] Adelalu, T.G. (2012) Climate Variability and River Benue Discharge in Jimeta, Yola Area, Nigeria. Hydrology for Disaster Management, Special Publication of the Nigerian Association of Hydrological Sciences.

[10] Lienou, G. (2013) Integrated Future Needs and Climate Change on the River Niger Water Availability. Journal of Water Resource and Protection, 5, 887-893. https://doi.org/10.4236/jwarp.2013.59090

[11] Haruna, G., Abubakar, I. and Tsoho, U. (2013) Fitting Probability Distribution Functions to Discharge Variability of Kaduna River. International Journal of Modern Engineering Research, 3, 2848-2852.

[12] Folorunsho, J.O., Iguisi, E.O., Mu'azu, M.B. and Garba, S. (2012) Application of Adaptive Neuro Fuzzy Inference System (Anfis) in River Kaduna Runoff Forecasting. Research Journal of Applied Sciences, Engineering and Technology, 4, 42754283.

[13] Deressa, T., Hassan, R.M. and Ringler, C. (2008) Measuring Vulnerability of Ethiopian Farmers to Climate Change across Regional States. IFPRI Discussion Paper No. 806, IFPRI, Washington DC.

[14] Birk, T. (2014) Assessing Vulnerability to Climate Change and Socioeconomic Stressors in the Reef Islands Group, Solomon Islands. Journal of Geography, 114, 59-75. https://doi.org/10.1080/00167223.2013.878228

[15] Eakin, H. and Luers, A.L. (2006) Assessing the Vulnerability of Social Environmental Systems. Annual Review of Environment and Resources, 31, 365-394. https://doi.org/10.1146/annurev.energy.30.050504.144352

[16] Smit, B. and Pilifosova, O. (2001) Adaptation to Climate Change in the Context of Sustainable Development and Equity, in Climate Change 2001: Impacts, Adaptation and Vulnerability, Chapter 18. Cambridge University Press, Cambridge.

[17] Hahn, M.B., Riederer, A.M. and Foster, S.O. (2009) The Livelihood Vulnerability Index: A Pragmatic Approach to Assessing Risks from Climate Variability and Change-A Case Study in Mozambique. Global Environmental Change, 19, 74-88. https://doi.org/10.1016/j.gloenvcha.2008.11.002

[18] Antwi-Agyei, P., Dougill, A.J., Fraser, E.D.G. and Stringer, L.C. (2012) Characterizing the Nature of Vulnerability to Climate Variability: Empirical Evidence from Two Regions of Ghana. Centre for Climate Change Economics and Policy Working Paper No. 105, Sustainability Research Institute Paper No. 37.

[19] Vincent, K. (2004) Creating an Index of Social Vulnerability to Climate Change for Africa. Working Paper 56, Tyndall Centre for Climate Change Research and School of Environmental Sciences, University of East Anglia, Anglia.

[20] Schröter, D., Polsky, C. and Patt, A. (2005) Assessing Vulnerabilities to the Effects of Global Change: An Eight Step Approach. Mitigation and Adaptation Strategies for Global Change, 10, 573-595. https://doi.org/10.1007/s11027-005-6135-9 
[21] ICIMOD (2011) Framework for Community-Based Climate Vulnerability and Capacity Assessment in Mountain Areas. ICIMOD, Kathmandu.

[22] Pandey, R. and Jha, S.K. (2012) Climate Vulnerability Index-Measure of Climate Change Vulnerability to Communities: A Case of Rural Lower Himalaya, India. $\mathrm{Mi}$ tigation and Adaption Strategies, Global Change, 17, 487-506. https://doi.org/10.1007/s11027-011-9338-2

[23] Huq, S. (2007) Community-Based Adaptation: An IIED Briefing. International Institute for Environment and Development, London.

[24] Gentle, P. and Maraseni, T.N. (2012) Climate Change, Poverty and Livelihoods: Adaptation Practices by Rural Mountain Communities in Nepal. Environmental Science and Policy, 21, 24-34. https://doi.org/10.1016/j.envsci.2012.03.007

[25] Gain, A.K., Giupponi, C. and Renaud, F.G. (2012) Climate Change Adaptation and Vulnerability Assessment of Water Resources Systems in Developing Countries: A Generalized Framework and a Feasibility Study in Bangladesh. Water, 4, 345-366. https://doi.org/10.3390/w4020345

[26] Oginni and Adebamowo (2013) An Evaluation of the Socio-Cultural Effects of Climate Change on Vulnerable Africa: Making A Case for Urgent Action towards Adaptation in Nigeria. British Journal of Arts and Social Sciences, 11, 259-267.

[27] Smith, B., Burton, I., Klein, R.J.T. and Wandel, J. (2000) An Anatomy of Adaptation to Climate Change and Variability. Climatic Change, 45, 223-251. https://doi.org/10.1023/A:1005661622966

[28] Folorunsho, J.O. (2004) An Examination of Some Stream Flow Characteristics of River Kaduna State. M.Sc. Thesis, Ahmadu Bello University, Zaria.

[29] Nkeki, F.N., Henah, P.J. and Ojeh, V.N. (2013) Geospatial Techniques for the Assessment and Analysis of Flood Risk along the Niger-Benue Basin in Nigeria. Journal of Geographic Information System, 5, 123-135. https://doi.org/10.4236/jgis.2013.52013

[30] Suleiman, Y.M. and Ifabiyi, I. (2014) The Role of Rainfall Variability in Reservoir Storage Management at Shiroro. International Journal of Science and Technology, 7, 55-63.

[31] Abdul-Gafar, A., Xu, S. and Yu, W. (2016) Perceptions of Rice Farmers towards Production Constraints: Case Study of Niger State of Nigeria and Hainan of China. Journal of Agricultural Chemistry and Environment, 5, 20-30. https://doi.org/10.4236/jacen.2016.51B004

[32] Turner, B.L., Kasperson, R.E., Matson, P.A., McCarthy, J.J., Corell, R.W., Christensen, L., Eckley, N., Kasperson, J.X., Luers, A., Martello, M.L., Polsky, C., Pulsipher, A. and Schiller, A. (2003) A Framework for Vulnerability Analysis in Sustainability Science. Proceedings of the National Academy of Sciences. Academy of Sciences of the United States of America, 100, 8074-8079. https://doi.org/10.1073/pnas.1231335100

[33] Adger, W.N. (2003) Social Capital, Collective Action and Adaptation to Climate Change. Economic Geography, 79, 387-404. https://doi.org/10.1111/j.1944-8287.2003.tb00220.x

[34] Vörösmarty, C.J., Green, P., Salisbury, J. and Lammers, R.B. (2000) Vulnerability from Climate Change and Population Growth. Science, 289, 284-288. https://doi.org/10.1126/science.289.5477.284

[35] Kelly, P.M. and Adger, W.N. (2000) Theory and practice in Assessing Vulnerability to Climate Change and Facilitating Adaptation. Climatic Change, 47, 325-352. https://doi.org/10.1023/A:1005627828199 
[36] Omonijo, T.O. and Okogbue, E.C. (2014) Trend Analysis of Drought in the Guinea and Sudano-Sahelian Climatic Zones of Northern. Atmospheric and Climate Sciences, 4, 483-507. https://doi.org/10.4236/acs.2014.44045

[37] Eze, J.N. (2006) Vulnerability and Adaptation to Climate Variability and Extremes: A Case Study of Flooding in Niger State, Nigeria. M.Sc. Thesis, University of the Witwatersrand, Johannesburg.

[38] Adakayi, P.E. (2012) An Assessment of the Rainfall and Temperature Variations in parts of Northern Nigeria. Ph.D. Thesis, University of Jos, Nigeria.

[39] Salarijazi, M., Ali-Mohammad, A.A., Adib, A. and Daneshkhah, A. (2012) Trend and Change-Point Detection for the Annual Stream-Flow Series of the Karun River at the Ahvaz Hydrometric Station. African Journal of Agricultural Research, 7, 4540-4552. https://doi.org/10.5897/AJAR12.650

[40] Okafor, G.C., Jimoh, O.D. and Larbi, K.I. (2017) Detecting Changes in Hydro-Climatic Variables during the Last Four Decades (1975-2014) on Downstream Kaduna River Catchment, Nigeria. Atmospheric and Climate Sciences, 7, 161-175. https://doi.org/10.4236/acs.2017.72012

[41] Ikehi, M.E., Onu, F.M., Ifeanyieze, F.O. and Paradang, P.S. (2014) Farming Families and Climate Change Issues in Niger Delta Region of Nigeria : Extent of Impact and Adaptation Strategies, Agricultural Sciences, 5, 1140-1151.

https://doi.org/10.4236/as.2014.512124

[42] Cervigni, R., Valentini, R. and Santini, M. (2013) Toward Climate-Resilient Development in Nigeria. Directions in Development. World Bank, Washington DC.

[43] Oyerinde, G.T., Hountondji, F.C.C., Wisser, D., Diekkruger, B., Lawin, A.E., Odofin, A.J. and Afouda, A. (2015) Hydro-Climatic Changes in the Niger Basin and Consistency of Local Perceptions. Regional Environmental Change, 15, 1627-1637. https://doi.org/10.1007/s10113-014-0716-7

[44] Adebayo, A.A., Onu, J.I., Adebayo, E.F. and Anyanwu, S.O. (2012) Farmers' Awareness, Vulnerability and Adaptation to Climate Change in Adamawa State, Nigeria. Arts and Social Sciences, 9, No. II.

[45] Mwakalila, S. (2011) Vulnerability of People's Livelihoods to Water Resources Availability in Semi-Arid Areas of Tanzania. Journal of Water Resource and Protection, 3, 678-685. https://doi.org/10.4236/jwarp.2011.39078

[46] Zhou, Y. (2013) Vulnerability and Adaptation to Climate Change in North China: The Water Sector in Tianjin. Research Unit Sustainability and Global Change, Hamburg University and Centre for Marine and Atmospheric Science, Hamburg, Germany.

[47] Ishaku, H.T., Majid, M.R., Ajayi, A.A. and Haruna, A. (2011) Water Supply Dilemma in Nigerian Rural Communities: Looking towards the Sky for an Answer. Journal of Water Resource and Protection, 3, 598-606.

https://doi.org/10.4236/jwarp.2011.38069

[48] Ishaku, H.T. and Majid, M.R. (2010) X-Raying Rainfall Pattern and Variability in Northeastern Nigeria: Impacts on Access to Water Supply. Journal of Water Resource and Protection, 2, 952-959. https://doi.org/10.4236/jwarp.2010.211113

[49] Sokoto, M.B. and Muhammad, A. (2014) Response of Rice Varieties to Water Stress in Sokoto, Sudan Savannah, Nigeria. Journal of Biosciences and Medicines, 2, 68-74. https://doi.org/10.4236/jbm.2014.21008

[50] Wiltshire, A., Gornall, J., Booth, B., Dennis, E., Falloon, P., Kay, G. and Betts, R. (2013) The Importance of Population, Climate Change and $\mathrm{CO}_{2}$ Plant Physiological Forcing in Determining Future Global Water Stress. Global Environmental Change, 23, 1083-1097. https://doi.org/10.1016/j.gloenvcha.2013.06.005 
[51] Ojo, O., Oni, F. and Ogunkunle, O. (2003) Implications of Climatic Variability and Climate Change on Water Resources Availability and Water Resources Management in West Africa. Water Resources Systems, Water Availability and Global Change, Proceedings of Symposium 1IS02, Sapporo, July 2003, IAHS Publication No. 280, 2003.

[52] Ellis, F. and Allison, E. (2004) Livelihood Diversification and Natural Resource Access. FAO, Livelihood Support Programme (LSP), Working Paper 9. ftp://ftp.fao.org/docrep/fao/006/AD689E/AD689E00.pdf

[53] Ford, J.D., Smit, B. and Wandel, J. (2006) Vulnerability to Climate Change in the Arctic: A Case Study from Arctic Bay, Canada. Global Environmental Change, 16, 145-160. https://doi.org/10.1016/j.gloenvcha.2005.11.007

[54] Paavola, J. (2008) Livelihoods, Vulnerability and Adaptation to Climate Change in Morogoro, CSERGE Working Paper EDM 04-12, Tanzania. Environmental Science and Policy, 11, 642-654. https://doi.org/10.1016/j.envsci.2008.06.002

[55] Okeola, O.G., Abdulkareem, K. and Raheem, A. (2016) Prioritization of Water Resources Management Problems in North Central Nigeria Using Rapid Impact Assessment Matrix (RIAM) Journal of Water Resource and Protection, 8, 345-357. https://doi.org/10.4236/jwarp.2016.83029

[56] McCubbin, S., Smit, B. and Pearce, T. (2015) Where Does Climate Fit? Vulnerability to Climate Change in the Context of Multiple Stressors in Funafuti, Tuvalu. Global Environmental Change, 30, 43-55. https://doi.org/10.1016/j.gloenvcha.2014.10.007

[57] Ifeanyieze, F.O., Ikehi, M.E. and Isiwu, E. (2014) Techniques in Utilizing Remote Sensor Technology for Precision Crop Production by Farmers as Climate Change Adaptation Strategy in Nigeria. Agricultural Sciences, 5, 1476-1482. https://doi.org/10.4236/as.2014.514158

[58] Kelkar, U., Narula, K.K., Sharma, V. and Chandna, U. (2008) Vulnerability and Adaptation to Climate Variability and Water Stress in Uttarakhand State, India. Global Environmental Change, 18, 564-574. https://doi.org/10.1016/j.gloenvcha.2008.09.003

[59] Obiora, C.J. (2014) Survival Strategies for Climate Change Induced Stress among Women Farmers in Benue State, Nigeria. Research on Humanities and Social Sciences, 4, 87-90.

Submit or recommend next manuscript to SCIRP and we will provide best service for you:

Accepting pre-submission inquiries through Email, Facebook, LinkedIn, Twitter, etc. A wide selection of journals (inclusive of 9 subjects, more than 200 journals)

Providing 24-hour high-quality service

User-friendly online submission system

Fair and swift peer-review system

Efficient typesetting and proofreading procedure

Display of the result of downloads and visits, as well as the number of cited articles

Maximum dissemination of your research work

Submit your manuscript at: http://papersubmission.scirp.org/

Or contact ajcc@scirp.org 